\title{
Strategi Pengembangan Usaha Produk Manufaktur di Pasar. Perdagangan Internasional
}

\author{
Oleh : Nur Feriyanto
}

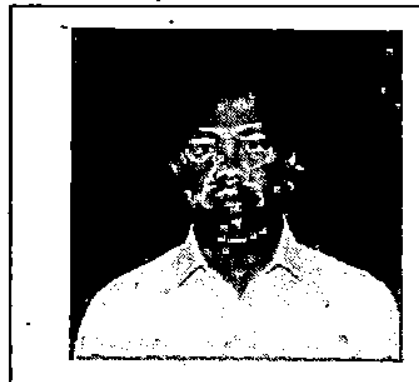

Drs. Nur Feriyanto, lahir di Yogyakarta tanggal 20 Februari 1960. Setelah menyelesaikan S-fnya diFEUII tahun 1984, dia mengabdikan dirinya di Almamaternya sampai sekarang. Jabatan struktural yang pernah disandangnya antara lain sebagai staf PD III FE UII, Kepala UPT Perpustakaan FE UII dan Ketua Jurusan. IESP FE UII. Selain itu, dia juga aktif dalam berbagai seminar dan penelitian.
Pendahuluan

Perjanjian GATT yang telah diratifikasi di Marrakesh (Maroko) bulan April 1994, yang kemudian berubah menjadi WTO(World Trade Organization) mulai 1 Januari 1995 merupakan peristiwa monumental bagi kalangan usahawan di Indonesia untuk mempersiapkan diri menuju perdagangan bebas. 'Banyak hal harus disiapkan sebelum waktụ perdagangan bebas yang mengandalkan mekanisme pasar dimulai tahun 2020. Bukan waktu yang panjang 25 tahun untuk berbenah, karena masih banyak hal didalam BUMN dan perusahaan swasta nasional yang harus diperbaiki untuk memasuki bisnis internasional yang bebas dari proteksi (perlindungan) pèmerintah tidak sebagaimana yang selama ini dinikmati para usahawan tersebut.

Perdagangan internasional yang bebas tentunya mempunyai dampak bagi perekonomian nasional yang mulai tahun 1990-an sudah mengurangi ketergantungan pendapatan dari ekspor migas. Tahuun 1988/1989 ekspor migas, 41,4\% dari pendapatan nasional, kemudian turun menjadi $23,9 \%$ pada tahun 1993/1994 dan diproyeksikan menjadi sebesar $16 \%$ pada Pelita VI. Sebaliknya pendapatan ekspor non migas mengalami peningkatan yang pesat rata-rata sebesar $24,2 \%$ per tahun dan pada Pelita VI diproyeksikan akan meningkat rata-rata pertahun sebesar $16,9 \%$.

\begin{tabular}{llll}
\multicolumn{4}{c}{$\begin{array}{c}\text { Eksport Indonesia } \\
\text { Tahun 1988/1989 - 1993/1994 } \\
\text { (nilai dalám juta US\$) }\end{array}$} \\
\hline Tahun & Migas & Non Migas & Total \\
$1988 / 89$ & 7.640 & 12.184 & 19.824 \\
$1989 / 90$ & 9.337 & 14.493 & 23.830 \\
$1990 / 91$ & 12.763 & 15.380 & 28.143 \\
$1991 / 92$ & 10.706 & 19.008 & 29.714 \\
$1992 / 93$ & 10.480 & 24.823 & 35.303 \\
$.1993 / 94$ & 9.172 & .28 .800 & 38.052 \\
\hline
\end{tabular}

*) Perkiraan realisasi

Sumber: Nota keuangan dan RAPBN TA 1994/95 
Tentunya bukan tugas yang ringan untuk mencapai target eksport tersebut. Lebih-lebih bilamana kita melihat export competitiveness produk manufaktur Indonesia pada tahun 1992/1993 masih belum optimal. Industri manufaktur Indonesia masih terlalu mengandalkan pasar dalam negeri, karena:daya saing yang dimiliki masih tergolong rendah. Dengan daya saing yang rendahtersebut maka menjadikan rasio antara nilai eksport dengan nilai produksi akan kecil. Hal ini dapat diamati rasio antara nilai eksport dengan nilai produksi industri kita tahun 1992/1993 yang menunjukkan bahwa untuk industri mesin, logam dasar dan elektronik rasionya hanya $8,40 \%$, industri kimia dasar $9,17 \%$, industri kecil $14,19 \%$ dan aneka industri $25,06 \%$ (Manajemen, April 1994)

Perkembangan ekonomi negaranegara berkembang rata-rata meningkat yaitu sebesar 3,7\% tahun 1990, kemudian meningkat menjadi 5,8\% tahun 1992 dan meningkat lagi sebesar $0,3 \%$ menjadi $6,1 \%$ pada tahun 1993. Tetapi untuk negaranegara maju justru mengalami penurunan pada pertumbuhan ekonomi negaranya yaitu tahun 1990 pertumbuhan ekonomi mencapai $2,3 \%$, kemudian menurun menjadi $1,7 \%$ pada tahun 1992 dan turun lagi menjadi $1,1 \%$ tahun 1993.

Sebagaimana diketahui bersama bahwa bisnis intemasional akan melibatkan transaksi bisnis yang dilakukan oleh dua pihak atau lebih yang melintasi dua batasan negara atau lebih. Pihak-pihak yang terlibat dalam transaksi tersebut dapat dari pemerintah (BUMN) atau swasta di dalam memperoleh tujuan usaha yaitu profit. Untuk dapat mencapai tujuan tersebut maka dibutuhkan kemampuan periguasaan faktor- faktor ekstemal dengan mengoptimalkan kemampuan intemal yang dimiliki. Faktorfaktorekstemal tersebut berupa faktorpasar dankompetitor yang akan dipengaruhi oleh kondisi geografi, hukum, budaya, politik ataupun ekonomi. Sedangkan faktor-faktor intemal dapat berupa faktor-faktor yang terkait dengan fungsi-fungsi usaha yaitu marketing, produksi, keuangan, akuntansi dan pengelolaan sumber daya manusia.

Bila perdagangan bebas telah dibuka, berarti bisnis intemasional akan terbuka secara adil untuk siapa saja yang siap untuk memanfaatkannya. Untuk dapat meraih peluang yang akan diperlukan kemampuan mengelola kemampuan yang dimiliki (faktor internal) secara optimal, mempelajari kondisi makro (faktor ekstemal) dan kemudian menyusun strategi yang tepat untuk mencapai tujuan yang dicanangkan. Karena jenis usaha yang dipilih adalah produk manufaktur maka strategi tersebut harus dapat tepat diterapkan untuk produk manufaktur pula.

\section{Motif Perusahaan Masuk ke Pasar Bisnis Internasional}

Terdapat beberapa motif pcrusahaan masuk ke pasar bisnis intemasional, yáng mendasari dari mengkombinasikan antara kemampuan intemal dan kemampuan mengantisipasi faktor makro (eksternal) perusahaan, yaitu:

\section{Terbukanya Pasar}

Dengan diratifikasi perjanjian perdagangan global, baik AFTA ataupun GATT (WTO) telah menjadikan pasar bagi siapa saja yang siap memamfaatkannya. Tidak ada lagi kuota, dumping, tarif dan kebijakan-kebijakan lain yang akan dapat menghambat masuknya suatu produk dan 
jasa di pasar bisnis internasional. Mekanisme pasarlah yang akan menentukan berhasil tidaknya suatu produk di pasar yang transparan ini.Terbukanya pasar berarti suatu produk dan jasa dapat masuk (impor) dan keluar (ekspor) dari suatu negara ke negara lain. Peluang ini sangat menguntungkan bagi barang yang mempunyai competitive advantage, walaupun sudah jenuh pemasarannya di dalam negeri, tetapi produk tersebut masih dapat dijual keluar negeri (ekspor).

2. Skala Ekonomis

Hanya produk yang siap berkompetisi di pasar bisnis intemasional yang akan bisa masuk ke pasar global dan menang di pasar tersebut. Menyadari hal itu maka diperlukan usaha yang komprehensif dari manajemen di dalam menghasilkan produk-produk yang kompetitif. Usaha tersebut dapat meliputi usaha memperoleh pembelian bahan baku yang murah karena jumlah pembelian yang besar, sehingga memperoleh discountharga beli. Pembelian yang cukup besar dalam bahan baku ini hanya mungkin bilamana skala produksi masih dalam skala ekonomis atau masih mempunyai kapasitas yang menganggur sehingga masih dapat dinaikkan jumlah produksinya. Skala ekonomis pada produksi ini hanya mungkin bilamana perusahaan masih mempunyai permintaan pasar yang belum terpenuhi. Keuntungan yang akan diraih adalah diperolehnya biaya produksi perunit (Average cost) yang rendah, market share yang lebih besar, pendapatan yang lebih tinggi dan keuntungan yang lebih besar. Tentunya usaha ini harus diikuti oleh pengawasan kualitas produk sehingga diperoleh kualitas yang tinggi dan harga jual yang kompetitif.,

\section{Kelebihan Jumlah Produksi}

Banyak akivitas pemasaran ke pasar bisnis internasional diawali dari kemampuan menguasai pasar domestik. Sehingga setelah menjadi market leader di negara sendiri mendorong peningkatan aktivitas perusahaan lebih besar lagi. Dengan kemampuan manajemen dan pengalaman di pasar domestik, mendorong peningkatan kapasitas produksi. Dengan peningkatan kapasitas produksi hal ini menjadikan perlunya diperoleh pasar yang lebih luas yaitu pasar internasional. Sehingga market share perusahaan akan dapat naik, meliputi pasar domestik dan menerobos pasar intemasional.

\section{Daya Saing pada Harga Produk}

Perbedaan kursnilai uang antarauang dalam negeri dengan uang intemasional (US dollar, Yen, Mark dsb), dapat menjadikan suatu produk akan kompetitif di pasar intemasional, tanpa perusahaan menurunkan harga jual ataupun dumping. Nilai tukar kurs asing yang lebih tinggi, menjadikan harga jual produk kompetitif. di pasar intemasional. Daya saing harga produk menjadi lebih kuat dibandingkan barang sejenis dari perusahaan asing. Kondisi ini dapat mendorong penjualan produk suatu perusahaan menerobos batas negara masuk ke pasar internasional.

\section{Produk Spesifik}

Barang spesifik adalah salah satu faktor yang juga dapat menjadi motif pengusaha untuk masuk dalam pasarbisnis internasional. Karena produk bersifat spesifik maka produk tersebut berarti memiliki corak, teknologi ataupun model yang ekslusif. Pada kondisi perekonomian dunia yang semakin baik dengan rata-rata pertumbuhan GNP di negara anggota APEC 
6-7\% per tahun tentunya konsumen akan sangat membutuhkan produk-produk bermutu tinggi dan ekslusif karena punya corak yang spesifik ini. Dengan usaha yang sungguh-sungguh produsen akan dapat menciptakan pasar yang terdiri dari konsumen barang-barang spesifik.

\section{Memiliki Teknologi}

Teknologi adaläh kedinamisan yang tidak dapat dihentikan olch waktu, schingga suatu produk dengan teknologi terbaru (paling canggih) akan mempunyai konsumen yang berdaya beli besar. Teknologi baru dan canggih diperoleh dari Departemen Research and Development (departemen R\&D) yang akan menjadikan produk yang memakai teknologi tersebut lebih kompetitif di pasar intemasional.

\section{Memiliki Informasi pasar yang dini, akurat dan lengkap}

Tidak dapat dipungkiri bahwa pasar yang semakin transparan ini mengharuskan suatu perusahaan yang masuk ke pasar bisnis intemasional harus mengenal benar dan menguasai kondisi internal dan ekstemalnya. Baik kemampuan perusahaan sendiri maupun kondisi pasar dan pesaing. Kondisi pasar dan pesaing akan cepat berubah, karenaadanya globalisasi disegala aspek di pasar internasional maka perusahaan membutuhkan informasi yang dini dan akurat. Sehingga strategi yang akan dilakukan perusahaan dapat tepat pada tujuan perusahaan.

\section{Bentuk Usaha dalam BisnisInternasional}

Untuk dapat memasuki pasar bisnis . intemasional kita perlu mengetahui secara tepat bentuk usaha dalam bisnis intemasional tersebut. Terdapat beberapa - bentuk usaha dalam bisnis internasional yaitu :

1. Ekspor dan Impor Barang Dagangan

Barang dagangan adalah "tangible good" yang dapat dijual keluar negeri (ekspor) atau dibeli dan didatangkan ke dalam negeri (impor). Usaha jenis ini akan mendatangkan suatu pendapatan dan pengeluaran dalam lingkungan global dan memerlukan manajemen yang kuat dan schat. Barang ekspor tentunya adalah barang-barang yang kompetitif di pasar global yang sangat dibutuhkan demand pasar global terscbut. Sedangkan barang impor adalah barang-barang yang secara ekonomis menguntungkan untuk dijual dalam negeri dan mempunyai kelebihan kompetitif dalam memuaskan selera dan kebutuhan konsumen yang membutuhkan, schingga aktivitas bisnis kedua jenis usaha tersebut dapat mendatangkan keuntungan yang baik.

\section{Investasi}

Investasi langsung disuatu negara adalah kepemilikan usaha yang mutlak sifatnya, baik dari segi manajemen ataupun dari kepemilikan asset usaha. Dengan dimilikinya saham perusahaan secara keseluruhan oleh pemilik modal maka pengawasan aktivitasperusahaan akanlebih muda, begitupula pelaksanaan strategi perusahaan akan dapat ditangani lebih terkonsentrasi tanpa campur tangan pihak lain.

\section{Perusahaan Multinasional}

Jenis usaha dengan aktivitas multinasional ini membutuhkan integrasi yang kuat antara perusahaan induk dengan perusahaan yang ada disuatu negara. Dengan dimilikinya bentuk perusahaan multinasional ini maka efisiensi dapat 
dilakukan, baik dari segi produksi, pemasaran ataupun keuangan. Karena dimungkinkan dilakukan transfer kebutuhan fungsi-fungsi usaha tersebut antara perusahaan induk dengan perusahaan di negara lain, tanpámembutuhkan birokrasi yang terlalu rumit karena" goal perusahaannya sama.

\section{Kinerja BUMN dan Swasta Indonesia}

Kinerja Badan Usaha Milik Negara dan Perusahaan Swasta adalah gambaran kinerja perckonomian nasional. Karena dua sektor inilah yang menjadi tulang punggung penggerak perekonomian nasional. Untuk dapat melihat kinerja ekonomi nasional mau tidak mau kita hanus menyoroti kinerja BUMN dan perusahaan swasta di Indonesia.

\section{Kinerja BUMN}

Jumlah BUMN di. Indonesia dari tahun ke tahun rata-ratả mengalami penurunan.Pada tahun 1988 tercatat berjumlah 189 kemudianmenurun menjadi 186 buah tahun 1990 dan tahun 1992 tinggal berjumlah 184 buah (tabcl 2)

Tabcl 2

Kinerja BUMN di Indonesia

Tingkat Keschatan Jumlah BUMN

198819901992.

Schat sckali

$\begin{array}{lll}35 & 60 & 43\end{array}$

Schat

$25 \quad 40$

43

Kurang schat

Tidak schat

$189^{`} 186184^{\circ}$

Jumlah

Sumber: Harian Bernas 14 September 1993

Tingkat kesehatan yang diberikan pada BUMN di Indonesia berdasarkan kriteria sebagai berikut:"

Sehat sekali: yaitu jika nilai bobot kondisi keuangan selama tiga tahun terakhir diatas 100 , dengan nilai rentabilitas diatas $12 \%$, likuiditas diatas $150 \%$ dan solvabilitas diatas $200 \%$.

Sehat: yaitu jika nilai bobot knondisi keuangan selama tiga tahun terakhir antara 68-100, dengan nilai rentabilitas antara $8 \%$, likuiditas antara 100\%-150\%, dan solvabilitas antara $100 \%-150 \%$.

Tidak sehat: yaitu jika nilai bobot kondisi keuangan selama tiga tahun terakhir tidak lebih dari 44 , dengan nilai rentabilitas kurang dari $5 \%$, likuiditas kurang dari $75 \%$ dan solvabilitas kurang dari $100 \%$.

Melihat perkembangan kesehatan kinerja BUMN, kita masih harus prihatin karena adanya penurunan perkembangan perbaikan kondisi kesehatan BUMN di Indonesia. Pada tahun 1988 dari 189 buah BUMN, yang sehat dan sehat sekali berjumlah 60 buah dan yang berstatus kurang sehat dan tidak sehat berjumlah $129^{\circ}$ buah. Untuk tahun 1990 dari 189 BUMN di Indonesia yang termasuk golongan sehat sckali dan sehat meningkat menjadi 100 buah dan yang masuk kategori kurang sehat dan tidak sehat menurun menjadi 86 buah. Tetapi pada tahun 1992 dari jumlah 184 buah BUMN yang masih masuk dalam kategori kurang sehat dan tidak sehat naik menjadi 89 buah, sedangkan untuk yang schat sekali dan sehat turun menjadi 95 buah.

Penurunan perkembangan kondisi kesehatan BUMN di Indonesia tersebut akan lebih memprihatinkan bilamana kita kaitkan dengan akan dibukanya pasar global tahun 2020 nantinya. Tentunya perlu

*). SK Menteri Keuangan No. 740/KMK 00/. 
usahả yang kerás dari departemen terkait untuk segera melakukan tindakan-tindakan yang akan dapat meningkatkan kondisi BUMN-BUMN yang masih tergolong kurang sehat dan tidak sehat tersebut.

\section{Kinerja Perusahaan Swasta}

Tidak dapat dipungkiri bahwa pihak yang paling dapat menikmati kue ckonomi Indonesia adalah perusahaan swasta yang

- berskala, besar. Berapa kebijakan. pemerintah ataupun regulasi yang ada masih terlalu menganak emaskan perusahaan besar atau konglomerat, dan masih sedikit yang menyentuh usaha kecil'. Dengan berbagai keistimewaan yang dimiliki pengusaha besar dapat berkembang dengan pesat. Hanya saja perlu diwaspadai bersáma, praktek bisnis yang hanya mengandalkan proteksi dari pemerintah tentunya bukanlah praktek bisnis yang sehat. Ekonomi biaya tinggi akan terus membebani masyarakat dengan harga produk yang tinggi, praktekpraktek monopoli, dan mark up dengan berbagai alasaan adalah inefisiensi yang harus segera dihentikan.' Bisnis internasional tidak akan memakai cara-cara monopoli, karenamckanisme pasarlah yang' akan menentukan perusahaan dapat survive dan berkembang. Produk yang berkompetitiflah yang akan dapat diterima di pasar global, yang ini hanya dapat diperoleh mélạui manajemen usaha yang efisien.

\section{Strategi Pengembangan Usaha Produk Manufaktur}

Untuk dapat mengembangkan usaha produk manufaktur di pasar perdagangan. internasional maka perusahaan dapat melakukàn Strategi Lingkungan (Enviroment Strategi) dan Strategi
Tehnologi Industri. Strategi lingkungan dilakkukan untuk mengantisipasi perusahaan kondisi pasar dan kompetitor, sedangkan strategi tchnologi industri digunakan untuk mengembangkan daya saing produk.

\section{Strategi Lingkungan}

Karena pasar terscbut merupakan pasar yang terbuka, ini mengandung arti bahwa siapapun yang mau dąn mampu bersaing, dapat masuk dan" "berlaga" di pasar ini. Untuk itu dibutuhkan usaha yang sungguh-sungguh untuk melakukan efisiensi diseluruh aspek perusahaan.

Karena hanya dengan melakukan usaha efisiensi, perusahaan akan mempunyai daya saing dan dapat survive di pasar internasional. scbab, pasar perdagangan internasional akan menggandalkan interaksi supply dan demand untuk menentukan' harga. Perilaku perusahaan yang menyimpang dari perilaku pasar bebas tentunya akan menjadi incfisiensi dan kalah dalam bersaing.

Proteksi dalam segala bentuk tidak ada lagi, karcna aturan-aturan perdagangan dunia (WTO) tidak memperbolehkan lagi. Praktek monopoli, oligopoli atau praktekpraktek yang tidak berdasarkan perdagangan bcbas tidak akan dijumpai lagi padaa pasar ini. Karena mekanisme pasar seccara otomatis lambat atau cepat akan menghilangkannya.

Untuk memenangkan kompetisi di pasar intemasional perusahaan harus dapat memanfaatkan secara optimal segala resourcés yang dimilki. Baik dari aspek produksi, pemasaran, keuangan, sumber daya manusia dán aspek intangible lainnya sepertigooswill, koneksi ataupun hubungan baik. Seluruh assets perusahaan tersebut haruslah dapat dimanfaatkan untuk 
mengungguti perusahaan pesaing.

Analisa SWOT (Strenghs, Weăknesses; Opportunities, Threats) harus dilakukan' perusahaan agar dapat berkembang secara sehat dalam kondisi persaingan yang ketat. Strengths dan Weaknesses yang merupakan faktor internal perusahaaan hendaknya menjadi perhatian, seluruh sumber daya yang ada agar dapat diakumulasikan secara positif, yaitu dengan meningkatkan kekuatan (Strengths) perusahaan dan mengeliminir kelemahan (Weakness) perusahaan. Dengan analisa SWOT itu pula Opportunities dan Threats yang merupakan faktorfaktor ekstemal dalam dapat dimanfaatkan dengan baik.

Melalui Benchmarking perusahaan dapat meniru dan kemudian mẹnciptakan produk yang lebih baik dari produk kompetitor. Didukung adanya TQM (Total Quality Management) yang baik, scbagai usahauntuk memperolch produk akhir yang dapat memenuhi kepuasan konsumen maka perusahaan akan mempunyai daya saing yang lebih kuat di pasar perdagangan internasional. Karena dengan TQM ini perusahaan dapat mendayagunnakan kualitas manajemen secarà optimal. Disamping itu pelayanan dari seluruh sumber daya yang ada untuk memberikan kepuasan pada konsumen dapat selalu ditingkatkan, yaitu lewat pemanfaatan, pengendalian dan pemanduan langkah-langkah yang operasional.

Pasar 'global yang terus menerus berubah karenakedinamisannyaperlu terus diamati agar dapat ditentukan langkahlangkah strategis untuk menangkap terciptanya peluarig-peluang dan tantangan pasar. Intelejen pemasaran untuk "mengintip" perusahaan kompetitor dan pasar dapat dilakukan, agar diperoleh informasi tentang kompetitor dan pasar secara akurat dan dini. Sehingga kebijakankebijakan yang dibuat oleh pimpinan dapat cepat dan tepat menangkap setiap peluang pasar dan mengantisipasi strategi kompetitor.

\section{Strategi Tehnologi Industri}

- Strategi ini dilakukan untuk memperbesar produktivitas tehnologi industri. Dengan semakin kuatnya tehnologi industri maka nilai tambah produk akan juga meningkat, yang berarti pula meningkatkan daya saing produk di pasar internasional. .

Integrasi dari perangkat keras dan lunak, sumberdaya manusia serta organisasi sangat berperan di dalam meningkatkan produkstivitas tehnologi industri, disamping dukungan Research Development and Engineering Departement.

Kemampuan memperoleh ligitimasi kualitas produkmelalui ISO-9000 tentunya merupakan langkah kongkrit mendukung -peningkatan daya saing produk di pasar pérdagangan intemasional. Karena dengan diperolehnya pengakuan produk melalui ISO-9000 ini kemampuan tehnologiproduk akan diakui oleh internasional dan mempermudah konsumen memperoleh jaminan kualitas produk.

\section{Kesimpulan}

Pengembangan usaha produk manufakturlndonesiadi pasarperdagangan intemasional dalam jangka pendek belum akan berkembang pesat; karena masih banyak kendala yang ada di kinerja BUMN dan swasta. Perlu dilakukan perubáhan yang 
berarti untuk memperbaiki kinerja tersebut melalui usaha yang sungguh-sungguh untuk melakukan ifisiensi disegala aspek perusahaan.

- Untuk memasuki pasar perdagangan internasional maka dapat dilakukan strategi lingkungan dan strategi tehnologi industri. Strategi lingkungan dilakukan untuk mengoptimalkan faktor-faktor internal untuk mengantisipasi faktor ekternal.(pasar dan kompetitor)

Sedangkan strategi tehnologi industri digunakan untuk meningkatkan nilai tambah produk sehingga diperoleh daya saing produk yang lebih tinggi. Strategi tehnologi industri ini mengandalkan interaksi yang kuat antara perangkat lunak dan keras, sumber daya manusia serta organisasi.

\section{$\therefore$ Referensi}

Daniels, Kohn D and Radcbaugh Lee H, International Business, Environmentsand Operations, Fifth Edition, AddisonWesley Publishing Company, 1989.

Guilinan, Joseph P and Paul, Gordon W, Marketing Management, Strategies and Programs, Third Edition, McGraw-Hill : Book'Company, New York, 1988.

Majalah Manajemen \& Usahawan Indonesia, No 04 TH XXIII April 1994.

Naylor, Vernon, Wertz, Corporate Economics and Strategy, 3rd Edition, Mc GrawHill Book Company, Tokyo, 1985.

Pride, Willian and Farel, Marketing, Concepts and Strategies, Sixth Edition, Houghton Mifflin Company, Boston, 1989.

Smith, Arnold and Bizzell, Business Strategy \& Policy, Second Edition, Houghton Mifflin Company, Dallas, 1988. 